The Economic Journal of Nepal, Vol.41, No. 3 \& 4, July-December 2018 (Issue No. 150) @ Cedecon-TU

\title{
Informal Economy and Poverty in Urban Nepal
}

\author{
Dipak Bahadur Adhikari ${ }^{1}$
}

\begin{abstract}
Informal sector plays crucial role in employing a significant part of the economically active population of Nepal. The Nepal Labour Force Survey (NLFS) - 2017/18 has estimated around 62 percent people to be currently employed in the informal sector. It is estimated that there are 84.6 percent of the currently employed who are informally employed in all industries as compare to formal employment 15.4 percent in Nepal. Employment is the main source of income of poor people which is still considered to be the most effective vehicle to take them out of poverty. People of rural areas are gradually coming to urban areas. So, economic growth and structural changes are increasingly linked to urbanization process. More people will live in urban settlements than in rural areas. Metropolitan cities of Nepal like Lalitpur can offer the lure of better employment, education, and health care and they also contribute disproportionately to the economy of the country. However, rapid urban expansion is often associated with poverty and rapid growth of informal sector urban area.
\end{abstract}

Key words: Informal economy, Employment, Income, Poverty JEL Classification: E26, E24, 13

\section{Introduction}

The informal economy is normally associated with poor, unproductive and excluded workers and its significance has varied in different economic periods (Gerxhani, 2004). Informal earnings are significant in middle income households and stronger in poorer households (Hieu et al., 2014). Income generation in the informal sector has been helpful in mitigating poverty in a big way. It has been a good mechanism for economic attainments when there is lack of sufficient economic opportunities elsewhere (Agrawal \&Dhakal, 2010). Poverty alleviation is a major agenda for sustainable development in developing countries like Nepal. However, poverty of Nepal has notably declined in current year. The decreasing trend in poverty rate from 41.8 percent in 1996 to 30.9 percent in $2004 ; 25.16$ percent in 2011 and 21.6 percent in 2015; and 18.7 percent 2018 (CBS, 2011; NPC, 2015 and 2018). The agenda of poverty alleviation not only includes the income raising activities but also constitutes the broadest opportunities in the economic development of the country.

$1 \mathrm{Mr}$. Adhikari is the Lecturer at Department of Economics, Patan Multiple Campus, TU, PatanDhoka, Lalitpur, Nepal. Email:dipak@pmcecodtu.edu.np , dipakadhikari10@ yahoo.com 
Informal sector plays crucial role in employing a significant part of the economically active population of Nepal. Informal sector provides the means of livelihood to millions of people in the country. It employs more than 96 percent of the economically active population in the country. Employment is the main source of income among the poor and most of them are found to be employed in informal sector. In most of the cases, however, the jobs are low-paid and the job security is poor (Suwal \& Pant, 2009). Informal sector absorbs surplus labours and provides income earning opportunities for the poor and that becomes a primary means of maintaining a low cost of living with cheaper goods and services (Bhatt, 2006).

In the urban context, the informal sector refers to small enterprise operators selling food or goods and offering services and thereby involving the cash economy and market transactions (Adhikari, 2011). Informal street food trade is taken as a means to provide low-cost food to a growing urban population of poor, unemployed, and low-wageworkers in Nepal (Adhikari, 2017). This urban informal sector is more diverse than the rural one and includes a vast and heterogeneous variety of economic activities through which most urban families earn their livelihoods.

\section{Review of Literature}

Sastry (2004) has quantified informal employment and poverty in India. This study used the international conceptual framework on the National Sample Survey Data of 1999-200. This survey was conducted 365 days to find the usual activity status. To classifying informal sector enterprises this study was used the ILO conceptual framework. The results revealed that 95 percent of all workers were in informal employment. Among them more proportion was females. In total, 96 percent of total jobs in rural areas were informal where 98 percent was female and 95 percent was male. In urban India, 79 percent of total jobs were of an informal nature where 82 percent of total female workers and 78 percent male workers. The study also analyzed that self-employed workers of urban area perform somewhat better and earns more than casual worker. Poverty is related more to the nature of employment than to be absolute tare of employment.

Nguyen et al., (2013) have analyzed informal economy as an engine for poverty alleviation in Vietnam. Secondary data has been used to link the informal economy with poverty. The 'Household Living Standard Survey' of Vietnam are the unique national surveys containing information about both employment and living standard have been used. The study revealed that the probability of being poor has decreased with the increase in the informal income. Further, the regression results also show that the probability of the household being poor is lower with the increase in education and vocational training of the household head. Further, the impact of informal income on poverty reduction is statistically positive.

Williams (2014) has shown the evidence and policy review on informal economy and poverty in United Kingdom (UK) to recognize whether informal economy helps those who are poor. This study mentioned that poor people are more likely to participate in informal economy. Their total income and wage rate are lower than for other groups. On the basis of survey conducted 
by Euro-barometer Survey - 2007 examine, 29 percent informal work was wage employment, 11 percent was self-employment and 60 percent was pain. Lower income population is more likely to take the form of paid favors for close social relations. In recent years, the approach of UK government has begun to shift away from eradication and towards facilitating its formalization. This report also supports this policy shift towards formalizing informal work.

Cichello and Rogan (2016) analyzed that employment in informal sector and poverty in South Africa is to identify the role of informal sources of income on poverty measures. Secondary data has been used to estimate the role of informal sector earning to poverty reduction. This research used 'Foster Greer Thorbecke (FGT)' to measures poverty. The result shows that government transfer and formal sector jobs are important determinant of poverty reduction whereas limited role plays in poverty reduction by informal sector at the national level. This is primarily obsessed by the fact that there are relatively few informal sector jobs compare to formal sector jobs. In the pre-job basis, the poverty reduction related with formal and informal sector job is quite similar. The informal sector self-employment jobs were providing just less 1.60 times the poverty reduction as formal jobs.

Barros and Chivangue (2017) discussed on poverty reduction through informal trade in Mozambique. The study contributed in literature by focusing on informal trade in Mozambique and it helps to establish the relationship between poverty reduction and informal trade. They used primary data through a set of questionnaires undertaken in the capital city of Mozambique, Maputo, in 2012. Stata software was used to checked heterogeneous logit model, which proved that the parameter estimation is in line. The results show that informal trade helps to decrease poverty and it is a strategy for the survival of low skilled individual household. They concluded that poverty decrease through informal trade and it is a wellestablished strategy in poor African countries. Informal economy is an alternative to absence of formal jobs and represents a strategy for evasion poverty.

Delbiso et al., (2018) described that informal sector and urban unemployment are related to small businesses contribution to large livelihood improvements. This study is based on primary data that were collected from 450 respondents related to informal sector by taking in detail interviews with stakeholders in Hawassa City of Ethiopia. They used ordinal logistic regression model to determine factors that affect the livelihood improvement with the help of choice variables. Their results indicate that there has been majority of the respondents witnessed livelihood enhancement after the informal business. About 62 percent were youth (10-24); nearly 45 percent operators were women and 63 percent were single. The bulk (90 percent) of the respondents has basic literacy. In general, nine out of ten operators witnessed improvement in their livelihood after they started operational in informal sector. Furthermore, around 82 percent of the respondents were able to meet their basic needs.

The given review of literature shows that it explored the relationship between informal sector and poverty but the sector-wise poverty has not been measured. This study seeks to establish the relationship between informal economy and poverty particularly related to urban areas of Nepal by utilizing the secondary sources of data basically from Nepal Living Standard Survey, NLFS, and primary data and information collected from Lagankhel area of Lalitpur Metropolitan City. 


\section{Objectives of the Study}

The objectives of the study are to show the contribution of informal sector on GDP at Continents level, SAARC level and national level along with analysis of the economic impact of informal sector in urban poverty in the Lalitpur Metropolitan City.

\section{Data and Methodology}

To measure the informal sector activities, various methods have been used in practice. In the case of Nepal, Labour Force Survey has used household survey method to collect the information of informal sector. This study is based on both secondary as well as primary data. The secondary data has been collected from periodic and annual reports of different government agencies and research articles. The primary data and information were based on street vendors of Lalitpur Metropolitan City which was collected in December, 2017. The major tools of data analysis are various tables, graphs, correlation, regression, multiple coefficient ofdeterminants, adjusted coefficient of determinants, t-test, and F-test using computer software STATA-14.

\section{Sampling Design}

The study focused on the street vendors of Lagankhel area of Lalitpur Metropolitan City - 12. The size of sample of the study was determined by observation method following a pilot survey. 120 vendors in the study area are selected randomly and they were interviewed individually by the researcher himself. The study area seems to be highly dominated by the rural migrated people as many respondents have been working for more than 25 years in the area. Most of the respondents are of semi-mobile nature only some are mobile nature. Most of the respondents who were in mobile and mobile-semi activities have been taken at their working places.

\section{Model and Variables Specification}

The model of the study is basically focused on how the earnings of street vendors have been affected by changing different explanatory variables. This is examining by using in multiple regression model. The general functional form of regression, the factors affecting the income of the street vendors of the Lalitpur Metropolitan city with explanatory variables is expressed as:

$$
Y=\beta_{0}+\beta_{1} I N V+\beta_{2} L S+\beta_{3} W Y+\beta_{4} A G E+e_{n}
$$

Where, $\mathrm{Y}=$ Income, INV= Initial investment; LS = labour supply; WY = working years; $\mathrm{AGE}=$ Age of the respondents, $\alpha=$ Constant term, $\beta_{0 \ldots .4}=$ Coefficients of parameters

In this model, income (Y) is a dependent variable and investment (INV), labour supply (LS), working years (WY) and age of street vendors (AGE) are explanatory variables. Income represents the monthly income of respondent. Investment indicates the money spent in the start-up phase of business. On the other hand, supply of labour indicates the total members of a worker involved in this sector. It causes the changes in the income of business-runners. Another effective factor in street business is working year. Persons who contribute more time, they do more income. Age of street vendors also affects income of street business. 
16 | The Economic Journal of Nepal (Issue No. 150)

Normally, young age of the respondents performs better than old age. Data are analyzed using OLS regression, and STATA-14 statistical software.

\section{Data Presentation and Analysis}

\section{World Scenario of Informal Economy}

It is not an easy task to calculate the informal sector contribution to GDP due to change in values price are primarily assumptions of national accountants. Those countries which prepare the household sector accounts in national income accounting system, there is a tentative estimate of the informal sector contribution which is possible to calculate (Charmes, 2012).

Table 1: Contribution of Informal Sector to GDP

\begin{tabular}{|l|c|c|}
\hline Continents & $\begin{array}{c}\text { Informal Sector (including } \\
\text { agriculture) in \% of Total GDP }\end{array}$ & $\begin{array}{c}\text { Informal Sector (excluding } \\
\text { agriculture) in \% of Total GDP }\end{array}$ \\
\hline Asia & 30.2 & 14.2 \\
\hline North Africa & 35.8 & 23.9 \\
\hline Sub-Sahara Africa & 63.6 & 31.3 \\
\hline Latin America & 29.2 & 24.0 \\
\hline Transitional Countries & 19.5 & 10.7 \\
\hline
\end{tabular}

Source: Charmes, 2012.

Table 1 shows that the contribution of informal sector to GDP including agriculture (63.6 percent) as well as non-agriculture (31.3 percent) is higher in Sub-Sahara Africa as compare to other continents. But the contribution of informal sector to GDP is lowest in transitional countries as compare to other continents.

Table 2: Non-agricultural Informal Employment

\begin{tabular}{|l|c|c|c|}
\hline \multirow{2}{*}{\multicolumn{2}{|c|}{ Continents }} & \multicolumn{3}{c|}{ Informal Employment } \\
& (\% of Non-agriculture Employment) \\
\cline { 2 - 4 } & Women & Men & Total \\
\hline Latin America and the Caribbean & 54 & 48 & 51 \\
\hline Sub-Sahara Africa & 74 & 61 & 66 \\
\hline Middle East and North Africa & 35 & 47 & 45 \\
\hline Eastern Europe and Central Asia & 7 & 13 & 10 \\
\hline South Asia & 83 & 82 & 82 \\
\hline East and Southeast Asia (excluding China) & 64 & 65 & 65 \\
\hline
\end{tabular}

Source: Vanek et al., 2014. 
Table 2 shows that the employment in non- agricultural sector of South Asia ( 82 percent)is higher as compare to other continents where as 66 percent in Sub-Saharan Africa, 65 percent in East and Southeast Asia, 51 percent in Latin America, 45 percent in Middle East and North Africa and only 10 percent in Eastern Europe and Central Asia. Informal employment is not attached only with informal sector but also large proportions of informal worker are available in formal sector.

\section{Informal Economy at SAARC}

In India, around 93 percent of industrial and service sector workforce engaged in informal sector in urban and sub-urban areas. Not surprisingly, these entire workforces are economically marginalized (Marjit \& Kar, 2007). More than two third (79.8 percent) workers in the South Asia region were in informal employment which was above the global average (ILO, 2013). Non-agriculture informal employment remains a major challenge in across the South Asia.

Table 3: Non-agriculture Informal Employment in South Asia

\begin{tabular}{|l|c|c|}
\hline Countries & Years & Informal employment (\% of Non-agriculture Employment) \\
\hline Bangladesh & 2010 & 88.5 \\
\hline Nepal & 2008 & 86.4 \\
\hline India & $2009 / 10$ & 83.6 \\
\hline Pakistan & $2009 / 10$ & 78.4 \\
\hline Sri Lanka & 2009 & 62.1 \\
\hline Maldives & n.a. & n.a. \\
\hline Afghanistan & n.a. & n.a. \\
\hline Bhutan & n.a. & n.a. \\
\hline
\end{tabular}

Source: ILO, 2013.

Table 3 shows that the contribution of informal economy to employment generation in South Asian region was very high. The non-agriculture employment of Nepal (86.4 percent) and Bangladesh ( 88.5 percent) were very high as compare to other South Asian countries like in India (83.6 percent), in Pakistan (78.4 percent) and in Sir Lanka (62.1 percent).

\section{Informal Economy in Nepal}

The informal sector represents an important part or economy in many countries like Nepal and it plays a key role in production, income generation and formation of employment (Adhikari, 2011). Informal employment has been defined as the total number of informal jobs, whether accepted in informal sector enterprises or households, formal sector enterprises (Hussmann, 2004). Around 70 percent of total non-agricultural employment aged 15 and over were currently employed in informal sector (NLFS, 2008). But the informal non-agriculture sector accounts only 41 percent of all jobs (NLFS, 2018). 
18 | The Economic Journal of Nepal (Issue No. 150)

Table 4: Total Formal and Informal Employment by Sector

\begin{tabular}{|l|c|c|c|}
\hline Sector of Employment & Male (in Percent) & Female(in Percent) & Total (in Percent) \\
\hline Formal & $\mathbf{4 0 . 3}$ & $\mathbf{3 3 . 5}$ & $\mathbf{3 7 . 8}$ \\
\hline Agriculture & 1.3 & 1.2 & 1.3 \\
\hline Non-agriculture & 39.0 & 32.3 & 36.5 \\
\hline Informal & $\mathbf{5 9 . 7}$ & $\mathbf{6 6 . 5}$ & $\mathbf{6 2 . 2}$ \\
\hline Agriculture & 13.4 & 31.8 & 20.2 \\
\hline Non-agriculture & 45.7 & 32.9 & 41.0 \\
\hline Private households & 0.6 & 1.8 & 1.0 \\
\hline \multicolumn{1}{|c|}{ Total } & $\mathbf{1 0 0}$ & $\mathbf{1 0 0}$ & $\mathbf{1 0 0}$ \\
\hline
\end{tabular}

Source: NLFS, 2018.

Table 4 shows that employment in informal sector is 62.2 percent as compare 37.8 percent in formal sector. The evidence clearly shows that the role of informal economy is very important to generate employment opportunity inNepal like other developing countries. In total employment was the non-agriculture informal sector along accounting for 41 percent of all jobs, the informal agriculture accounting for 20.2 percent while private households accounted for 1 percent of total employment. In Nepal, informal employment includes employers, contributing family workers, informal sector's own-account workers who are employed in informal sector, as well as employees and paid apprentices who do not have paid annual leave or sick leave benefit and whose employers do not contribute to their social security (NLFS, 2018).

Table 5: Formal and Informal Employment (in percent)

\begin{tabular}{|l|c|c|c|}
\hline \multicolumn{1}{|c|}{ Occupation } & Formal Employment & Informal Employment & Total \\
\hline Total & 15.4 & 84.6 & 100 \\
\hline Formal sector & 40.8 & 59.2 & 100 \\
\hline Informal sector & 0.0 & 100.0 & 100 \\
\hline
\end{tabular}

Source: NLFS, 2017/018

Table 5 shows that the informal employment is higher ( 84.6 percent) as compare to formal employment (15.4 percent) in Nepal. In formal sector, only 40.8 percent workers are employed in formally whereas 59.2 percent are employed informally. They do not have to sick leave and paid annual leave benefits and their employers do not contribute towards their social security.

Table 6: Share of Informal Employment by Sector

\begin{tabular}{|l|c|c|}
\hline \multicolumn{1}{|c|}{ Occupation } & Informal Employment (in thousands) & In percent \\
\hline Total & 5994 & 100 \\
\hline Formal Sector & 1583 & 26.4 \\
\hline Informal Sector & 4411 & 73.6 \\
\hline
\end{tabular}

Source: NLFS, 2018. 
Table 6 shows that above 15 years employed people are 84.6 percent informally. Among them, 73.6 percent are in informal sector and 26.4 percent are in formal sector.

\section{Sector-wise Poverty in Nepal}

The poverty and informal sector have close relationships. They may have causal relationship between them. However, informal sector pays low wage rate in comparison to formal sector. The NLSS - 2010/11 estimates that 25 percent of people are living below the absolute poverty line in Nepal. Therefore, informal sector may be one of the important determinants of poverty in Nepal as shown in given table 7.

Table 7: Poverty by Occupation of Household Head (in percent)

\begin{tabular}{|l|c|c|c|c|c|}
\hline \multirow{2}{*}{ Sectors } & \multicolumn{3}{c|}{ Poverty Index } & \multicolumn{2}{c|}{ Distribution of Poverty } \\
\cline { 2 - 6 } & Incidence & Intensity & Sensitivity & Of the Poor & Of the Population \\
\hline \multicolumn{5}{|c|}{ Main Occupation of Household Head } \\
\hline $\begin{array}{l}\text { Self-Employment } \\
\text { Agriculture }\end{array}$ & 27.23 & 6.00 & 2.05 & 55.20 & 51.00 \\
\hline Manufacturing* & 22.44 & 5.03 & 1.77 & 3.80 & 4.20 \\
\hline Trade & 13.21 & 2.54 & 0.74 & 4.10 & 7.90 \\
\hline Services & 19.63 & 3.33 & 1.02 & 2.00 & 2.60 \\
\hline & \multicolumn{5}{|c|}{ Wage } \\
\hline Agriculture & 47.03 & 8.56 & 2.52 & 6.30 & 3.40 \\
\hline Professional & 5.55 & 1.14 & 0.35 & 0.70 & 3.30 \\
\hline Other & 28.25 & 5.76 & 1.73 & 16.20 & 14.50 \\
\hline $\begin{array}{l}\text { Extended } \\
\text { economic activity }\end{array}$ & 31.55 & 9.37 & 3.67 & 5.90 & 4.70 \\
\hline Unemployed & 26.65 & 3.60 & 0.86 & 0.40 & 0.40 \\
\hline Inactive & 16.63 & 3.35 & 1.09 & 5.30 & 8.00 \\
\hline Nepal & 25.16 & 5.43 & 1.81 & 100.00 & 100.00 \\
\hline
\end{tabular}

Note: An asterisk * shows manufacturing workers in mining, quarrying, construction, electricity and utilities.

Source: NLSS, 2011.

Table 7 shows that poverty in agriculture sector is found 27 percent which is close to the poverty rate of unemployed. Poverty in agriculture-based wage is found almost 50 percent which is higher compared to another sector. Poverty in manufacturing sector including workers in mining and quarrying, construction, electricity and utilities as well found around 22.44 percent. Similarly, poverty found in trade 13.21 percent and service sector 19.63 percent. Similarly, poverty in agriculture-based wage is found almost 50 percent which is higher compared to another sector such as professional sector found only around 5 percent. It suggests that poverty and informal sector have close relationships. They may have causality 
20 | The Economic Journal of Nepal (Issue No. 150)

relationship; however, informal sector pays low wage rate compared to formal sector. Therefore, informal sector may be one of the important determinants of poverty in Nepal.

\section{Correlation Analysis}

Correlation analysis measures the degree of association and direction of relationship between two or more variables. It is a quantitative assessment that measures both the direction and strength of a linear relationship between two variables. The study used Pearson's correlation coefficient as a test statistic. Itis to analyze the degree of relationship between income (Y) of individual street vender in the study area with its major determinants like investment (INV), labour supply (LS), working years (WY), and age of individual (AGE) of street vender in the study area. Pearson's coefficients of correlation have been presented in the table 8 .

Table 8: Correlation Matrix between the Variables

\begin{tabular}{|l|c|c|c|c|c|}
\hline \multicolumn{1}{|c|}{ Variables } & Income (Y) & $\begin{array}{c}\text { Investment } \\
\text { (INV) }\end{array}$ & $\begin{array}{c}\text { Labour } \\
\text { Supply (LS) }\end{array}$ & $\begin{array}{c}\text { Working } \\
\text { Years (WY) }\end{array}$ & Age (AGE) \\
\hline Income (Y) & 1 & & & & \\
\hline Investment (INV) & 0.51 & 1 & & & \\
\hline Labour Supply (LS) & 0.46 & 0.36 & 1 & & \\
\hline Working Years (WY) & 0.16 & -0.03 & 0.23 & 1 & \\
\hline Age (AGE) & 0.04 & 0.07 & 0.17 & 0.48 & 1 \\
\hline
\end{tabular}

Source: Author's calculation.

Table 8 shows that the Investment, labour supply, working years and age are positively correlated with income. It implies that increase in all the given variables leads to higher level of income. The coefficient of correlation between income (Y) and investment (INV) is 0.51 which shows that both of them are moderate positive relationship. Likewise, the coefficient of correlation between income (Y) and labour supply (LS) is 0.46 which shows that both of them are low degree of correlation to each other. Similarly, the coefficient of correlation between income (Y) and working years (WY) is 0.16 which shows that both of them have very low degree of correlation to each other. Moreover, the coefficient of correlation between income (Y) and age (AGE) of individual street vender is 0.04 which shows that both of them have very low degree of correlation.

\section{Regression Analysis}

The multiple regression analysis shows the linear role of independent variables to the given dependent variable in order to examine the any given units change in given independent (explanatory) variables to the estimated units change in dependent variable (Y). In the study, the income (Y) is taken as the dependent (response) variable and investment (INV), labour supply (LS), working years (WY) and age (AGE) of individuals street vendors are taken as independent (explanatory) variables as shown in given model and table 9. 


$$
\begin{gathered}
\mathrm{Y}=\beta_{0}+\beta_{1} \mathrm{INV}+\beta_{2} \mathrm{LS}+\beta_{3} \mathrm{WY}+\beta_{4} \mathbf{A G E}+\mathrm{e}_{\mathrm{n}} \\
\mathrm{Y}=9,843+0.0598 \mathrm{INV}+3,786 \mathrm{LS}+303.4 \mathrm{WY}-111.4 \mathbf{A G E}+\mathrm{e}_{\mathbf{n}}
\end{gathered}
$$

\begin{tabular}{|c|c|c|c|c|c|}
\hline Variables & Parameters & $\begin{array}{l}\text { Constant \& } \\
\text { Coefficients }\end{array}$ & $\begin{array}{c}\text { Standard } \\
\text { Error }\end{array}$ & $\mathrm{t}$ - value & Prob. \\
\hline Constant & $\boldsymbol{\beta}_{0}$ & $9,843 * * *$ & 2,967 & 3.32 & 0.001 \\
\hline Initial investment (INV) & $\boldsymbol{\beta}_{1}$ & $0.0598 * * *$ & 0.0117 & 5.09 & 0.000 \\
\hline Labour Supply (LS) & $\beta_{2}$ & $3.786 * * *$ & 1,087 & 3.48 & 0.001 \\
\hline Working years (WY) & $\boldsymbol{\beta}_{3}$ & $303.4^{*}$ & 168.4 & 1.80 & 0.074 \\
\hline Age of respondents (AGE) & $\beta_{4}$ & -111.4 & 91.21 & -1.22 & 0.224 \\
\hline
\end{tabular}

Table 9: Results of Regression Analysis for Determinants of Income

Note: Standard errors in parentheses. ${ }^{* * *} \mathrm{p}<0.01,{ }^{* *} \mathrm{p}<0.05,{ }^{*} \mathrm{p}<0.10$.

\section{Source: Author's calculation.}

The given table 9 reveals that 36.09 percent of the total variation in income is explained by the variation in the given all independent (explanatory) variables like investment, supply of labour, working years and age. Similarly, 33.86 percent of the total variation in income is explained by the given fitted regression. Again, the P-value (0.000) for overall goodness of fit in the model is lesser than $\alpha$ value $(\alpha=0.01)$ so that the model is statistically significant even at one percent level of significance. Hence, it could be concluded that the regression equation is significant by rejecting null hypothesis of the study.

The coefficient of investment variable is positive that shows any increase in investment brings increase in income of the vendors. The coefficient indicates that NRs. 1 increase in investment brings near about NRs. 0.0598 increase in income per month of the vendors. Again, the P-value (0.000) for investment in the model is lesser than $\alpha$ value $(\alpha=0.01)$ so that the model is statistically significant even at one percent level of significance. Hence, it could be concluded that investment is an important variable that brings significant and positive effect in street income of vendors and significant at one percent level by rejecting null hypothesis of the study.

Similarly, the results reveal that labour supply has great significant impact in bringing change in income earned by the vendors. The positive sign of coefficient indicates that increase in labour by one unit, increases the income of street vendors by around NRs. 3,786 per month. It is significant at one percent level.

Again, the result reveals that working year is another important variable affecting the incomes of street vendors. The positive coefficient of working years of street vendors indicates that increase in one more experience year, increases the income of the street vendors 
by around NRs. 303.4 per month. The variable is found significant to bring about the change to income. It is significant only at ten percent level.

Finally, age of the street vendors is another important variable which is being a negative coefficient. It indicates that when age of street vendors increases, the probability of their capacity to generate income decreases and vice versa. But it is not found significant even at ten percent level of significant in this analysis.

\section{Conclusions}

Informal sector plays the significant role in to the economy of nation. It helps to reduce poverty, unemployment and inequality without government policies and programmes. Thus, it creates selfemployment opportunity and raises their leaving standard. Some argues that the urban informality is increases after the liberalization of cities as one of the consequences of globalization (AlSayyad, 2004). On the other hand, rural-urban migration is the main cause which leads to increase urban informal sector. Those people who recently migrant in the city, urban informal sector provides as significant entry point (Koo \& Smith 1983). The urban areas tend to offer better public services and urban informal sector offers better opportunities than the rural economic sector. Earnings are higher in urban informal employment than in rural occupations. In many countries including Nepalese cases, in the initial phase of urbanization informal economic activities are very high.

Poverty in Nepal is compounded by general uncertainty with respect to livelihood and life, which threatens an even wider section of the population than might be counted as poor. Poverty is an extremely complex phenomenon, which manifests itself in a range of overlapping and interlinked among economic, political and social deprivations. Benefits of development are not widely spread to various sections in society. Some are left behind and some others are not touched by the benefits of development. Those people who are far from the development activities in a nation, these are usually used to do informal jobs and survived their lives.

\section{Acknowledgements}

The issue of the paper is related to the $\mathrm{Ph}$. D. work of the author. So, I am thankful to the University Grant Commission for the Ph.D. fellowship support by UGC award number (according to the agreement) that is $\mathrm{Ph}$. D. $-74 / 75 / \mathrm{H} \& \mathrm{~S}-05$.

\section{References}

Adhikari, D. B. (2011). Income generation in informal sector: A case study of the street vendors of Kathmandu metropolitan city. Economic Journal of Development Issues, $13 \& 14(1-2)$.

Adhikari, D. B. (2017). Informal street food trade: A source of income generation in urban Nepal. Economic Journal of Development Issues, 1-17.

Aagarwal, M.K., \& Dhakal, R. C. (2010). Informal sector and income generation in Nepal: A case of Chitwan district. Indian Journal of Labour Economics, 53(2).

Avasthy, D., Ray, A. K., \& Deb, R. (2013). Women informal economy: Its characteristics and legitimacy in the intergenerational context. Cuadernos Hispanoamericanos, 13(1), 4-12.

Barros, C., \& Chivangue, A. (2017). Poverty reduction and informal trade. Working Paper CESA CSG $151 / 2017$. 
Bhatt, E. R. (2006). We are poor but so many: The story of self-employed women in India. Oxford University Press.

CBS (Central Bureau of Statistics) (2008). Statistical Report-2007/8. CBS, National Planning Commission Secretariat (NPCS, Government of Nepal (GoN).

CBS (Central Bureau of Statistics) (2009). Nepal Labour Force Survey 2007/08-Statistical Report. CBS, NPCs, GoN.

CBS (Central Bureau of Statistics) (20112). Nepal Living Standard Survey 2010/11: Statistical Report. Volume I \& II. CBS, NPCS, GoN.

CBS (Central Bureau of Statistics) (2018). Nepal Labour Force Survey 20017/18-Statistical Report. CBS, NPCS, GoN.

Charmes, J. (2012). The informal economy worldwide: Trends and characteristics. The Journal of Applied Economic Research, 6(2), 103-132.

Chen, M. A., Vanek, J., \& Carr, M. (2004). Mainstreaming informal employment and gender in poverty reduction: A handbook for policy-makers and other stakeholders. Commonwealth secretariat.

Cichello, P., \& Rogan, M. (2016). Informal sector employment and poverty in South Africa: Identifying the contribution of 'informal' sources of income on aggregate poverty measures. Paper for ISEP Book Project. F. Fourie \& C. Skinner. Tackling unemployment and poverty in South Africa: The contribution of the informal sector.

Coletto, D. (2010). The informal economy dilemmas: Old and new views. The Informal Economy and Employment in Brazil (pp. 1-42). New York: Palgrave Macmillan.

Delbiso, T. D., Deresse, F. N., Tadesse, A. A., Kidane, B. B., \& Calfat, G. G. (2018). Informal sector and urban unemployment: Small businesses contribution to large livelihood improvements. International Journal of Entrepreneurship and Small Business, 34(2), 169-182.

Gërxhani, K. (2002). The informal sector in transition: Tax evasion in an institutional vacuum. Amsterdam: Thela Thesis.

Guha-Khasnobis, B., Kanbur, R., \& Ostrom, E. (2006). Beyond formality and informality. Linking the Formal and Informal Economy: Concepts and policies, 4, 75-92.

Hart, K. (1973). Informal income opportunities and urban employment in Ghana. The Journal of Modern African Studies, 11(1), 61-89.

Hieu, N. T. M., Giang, N.T.H., Ngoc, V.T.M., Duc, N.V, \& Quan, T.T. (2014). Does the informal economy mitigate poverty and how does it work? The case of Vietnam. Mekong Economic Research Network, Hue College of Economics, Vietnam Forestry University. 
24 | The Economic Journal of Nepal (Issue No. 150)

Hussmann, R. (2004a). Defining and measuring informal employment. Bureau of Statistics, International Labour Office. Geneva.

Hussmann, R. (2004b). Measuring the informal economy: From employment in the informal sector to informal employment. Working paper, No.53. Geneva, Switzerland: ILO.

ILO (International Labour Organization) (1972). Employment, Income, and Equality. A Strategy for Increasing Productive. Geneva.

ILO (International Labour Organization) (2013). Women and Men in Informal Economy: A Statistical Picture. Geneva: International Labour Office.

Koo, H., \& Smith, P. C. (1983). Migration, the urban informal sector, and earnings in the Philippines. The Sociological Quarterly, 24(2), 219-232.

Marjit, S., \& Kar, S. (2007). The urban informal sector and poverty: Effects of trade reform and capital mobility in India. Retrieved from https://papers.ssrn.com/sol3/ papers.cfm?abstract_id $=968655$

Moser, C. O. (1978). Informal sector or petty commodity production: Dualism or dependence in urban development? World Development, 6(9-10), 1041-1064.

Nguyen, T. M. H., Nguyen, T. H. G., Vu, T. M. N., \& Nguyen, V. D. (2013). Whether or not the informal economy as an engine for poverty alleviation in Vietnam.

NPC (National Planning Commission) (2015). The Eleventh Three Years Interim Plan (2015-2017). Retrieved from https://www.npc.gov.np/images/category/14th-planfull-document.pdf

NPC (National Planning Commission) (2018). The Fifteenth Plan - Approach Paper (20192024). Kathmandu, Nepal: NPC, GoN.

Raj, M., \& Mitra, B. (1990). Households, housing and home-based economic activities in low income settlements. Housing and Income in Third World Urban Development. London: Aspect Publishing.

Sastry, N. S. (2004). Estimating informal employment \& poverty in India. New Delhi, India: Human Development Resource Centre.

Suwal, R. \& Pant, B. (2009). Measuring informal sector economic activities in Nepal. Paper prepared for the Special IARIW-SAIM Conference on Measuring the Informal Economy in Developing Countries. Kathmandu, Nepal, September 23-26, 2009.

Vanek, J., Chen, M. A., Carré, F., Heintz, J., \& Hussmanns, R. (2014). Statistics on the informal economy: Definitions, regional estimates and challenges. Women in Informal Employment: Globalizing and Organizing (WIEGO) Working Paper (Statistics), 2, 47-59.

Williams, C. (2014). The informal economy and poverty: Evidence and policy review. Report prepared for Joseph Rowntree Foundation, York. 